\title{
Investigating a theoretical framework for e-learning technology acceptance
}

\author{
Barween Al Kurdi', Muhammad Alshurideh², Said A. Salloum ${ }^{3}$ \\ ${ }^{1}$ Marketing Department, Amman Arab University, Jordan \\ ${ }^{2}$ Management Department, University of Sharjah, United Arab Emirate \\ ${ }^{2}$ Faculty of Business, University of Jordan, Jordan \\ ${ }^{3}$ Research Institute of Sciences and Engineering, University of Sharjah, United Arab Emirate
}

\begin{tabular}{l} 
Article Info \\
\hline Article history: \\
Received Mar 31, 2020 \\
Revised Jun 6, 2020 \\
Accepted Jun 17, 2020 \\
\hline Keywords: \\
E-learning system \\
Perceived ease of use \\
Perceived enjoyment \\
Perceived usefulness \\
Self-efficacy \\
Social influence \\
Technology acceptance model \\
University students
\end{tabular}

\begin{abstract}
E-learning has gained recognition and fame in delivering and distributing educational resources, and the same has become possible with the occurrence of Internet and Web technologies. The research seeks to determine the factors that influence students' acceptance of E-learning and to find out the way these factors determine the students' intention to employ E-learning. A theoretical framework was developed based on the technology acceptance model (TAM). To obtain information from the 270 university students who utilized the E-learning system, a questionnaire was formulated. The results revealed that "social influence, perceived enjoyment, self-efficacy, perceived usefulness, and perceived ease of use" are the strongest and most important predictors in the intention of and students towards E-learning systems. The outcomes offer practical implications for practitioners, lawmakers, and developers in effective E-learning systems implementation to improve ongoing interests and activities of university students in a virtual E-learning atmosphere, valuable recommendations for E-learning practices are given by the research findings, and these may turn out to be as guidelines for the efficient design of E-learning systems.
\end{abstract}

Copyright $@ 2020$ Institute of Advanced Engineering and Science. All rights reserved.

\section{Corresponding Author:}

Said A. Salloum,

Research Institute of Sciences and Engineering, University of Sharjah, UAE,

Academic City Road, P. O.Box 27272 Sharjah, United Arab Emirate.

Tel: +9716 5585000, Fax: +97165585099

Email: ssalloum@sharjah.ac.ae

\section{INTRODUCTION}

The use of world wide web (WWW) has expanded to a large extent in the previous two decades, because of which investments are being made by universities and other educational institutes in information systems (like Moodle and Blackboard), which endorse face-to-face [1-3] as well remote course delivery [4-6]. Even though the internet is viewed as a global technology, it is important to measure the effectiveness of these tools at the domestic level because users are typically employed in local/national contexts [7].

The effective use of E-learning tools is dependent on the perspective of the users, as well as their knowledge and competences with respect to both computer and mobile usage [6, 8-10]. It has been found that these significant factors have an impact on the early acceptance [11] of the users of computer technology and their behavior in the future $[6,12-15]$ with respect to the use of web-based learning systems [16]. Since the technology acceptance model (TAM) has satisfactory explanatory power and its widespread popularity, it was used in various studies in the technology acceptance and adoption literature in the domain of IS implementation [17], particularly in terms of E-learning [18-21]. However, there is insufficient evidence to determine if this model is appropriate for E-learning in emerging countries and the Arab nations. Hence, 
the reliability and validity of TAM, as well as its generalizability, remain questionable because it was condemned for its cultural discrimination, mainly when evaluated in non-western countries [22].

There are other issues inherent in TAM as well, for example, the irregularities in the previous studies, and its inefficiency in justifying the social influence on the acceptance of technology [8, 22, 23]. These limitations will be addressed in the study by extending TAM so that it incorporates other factors like social influence" [17], "perceived enjoyment" [24], "self-efficacy". The key objectives of this study are to cater to the limitations discussed earlier. The research particularly stresses the factors that have an impact on student's acceptance [11] and usage of web-based learning systems [25] in the context of the Arab world, especially in Jordan as a cultural context and Moodle as a web-based learning system. The structure of the paper is presented below: The following section presents a literature review. Section 3 discusses the research model and hypotheses that were used in the study. In Section 4, the analysis and findings of the data collection are explained. Section 5 presents the findings and discussions, while the final section presents a conclusion of the paper with the key findings.

\section{LITERATURE REVIEW}

\subsection{E-learning in higher education}

Within the learning environment of the universities, innovations, and opportunities are created by the swift developments of information technology. A Web-based learning platform is offered by E-Learning with a practical and flexible context, which can then strengthen both learner and teacher [26-28]. With the adoption of E-learning, the knowledge is shared among masses at large through the tools and systems, for example, Internet [29], Intranet [30, 31], email [32], chat [33, 34], discussion groups [35, 36], wikis [37, 38], blogs [27, 39, 40]. We can enjoy numerous services through E-learning, and in line with the students' needs, knowledge, exposure, and expertise, we can also customize these services [41]. To improve access to higher education and to bring efficiency in the quality of learning across universities, the university education system in UAE has implemented the E-learning tools [42]. We can assume the E-learning as a facilitator for the teaching-learning process [27]. As compared to the traditional learning systems, various benefits are offered by the E-learning for the university students. The time, place and people are needed in the traditional learning system, while the E-learning has no boundaries of learning. We can utilize this limitless learning system at anytime and anywhere. Since E-learning is a technology-based system, it should be understood by the developers and the deliverers that how the users observe and respond to the E-learning systems. Foregoing in view, an insight will thus be gained to effectively design and efficiently deliver the E-learning approach, so that the overall learning experience could be enhanced.

\subsection{The technology acceptance model}

While several universities have locally developed e-learning systems in UAE within their campuses, the acceptance of the university students will determine the success of the system. There are two levels to analyze the adoption of technology, which is either through individual and organization [43]. This study aimed at the individual level, so the university students currently using the E-learning system in their day to day learning process were taken into active consideration. The research model of this study was based on the technology acceptance model (TAM) [44, 45], which is the well-known model to justify "the technology acceptance behavior" among users and this milestone can be achieved by implementing this model [46].

In many earlier studies, the researchers have been using TAM to represent the theoretical model [21, 24, 47-49]. This was based on "users' perceived acceptance of any technology". The TAM was considered as the base model with some integrated factors so that the attitude towards using E-learning could be explored besides analyzing the behavior of intention to use it. As per TAM, two main factors determine the acceptability of technology, which are: perceived ease of use and perceived usefulness, see Figure 1. Perceived ease of use explains the degree to which a person believes that there would be no trouble in using such a technology. Moreover, perceived usefulness is the degree to which a person believes that his/her job performance will be improved with such a technology. According to a number of factorial analyses, we can consider the perceived ease of use and perceived usefulness as two different dimensions of human beings $[50,51]$. It is clear that if only one option is to be chosen from the two systems having similar attributes, then the preference of the users will be the one containing easier and user-friendly features [52]. The original version of TAM is given in Figure 1 [45].

\subsection{Determinants of students' acceptance of E-learning}

With the adoption of TAM, the critical factors for the acceptance of E-learning had been identified by several researchers [24, 54-62]. Regarding this study, the goal was to analyze the E-learning acceptance behavior of the UAE University students, through whom, better understandings of implications to implement 
E-learning systems in UAE universities successfully could be gained. This study only aimed at the students engaged in computing degrees in the UAE university system.

Several research studies analyzed the effect of specific student features upon the acceptance and implementation on online technology. These studies have been included as part of the E-learning research [47, 63-72]. Based on the perceived ease of use, the online delivery system may be preferred by the students keeping in mind their ability to make use of the internet and other kinds of electronic communication systems. These students are also interested in individual learning. The academic achievements as part of the online system are also positively influenced by the individual's perception towards the online learning usefulness [73]. Other factors associated with individuals' attributes are the social influence made by the student reference groups and student's outlook concerning online learning, and these may influence their willingness to learn online $[74,75]$. It is the behavioral intention of the users that has a powerful impact on their actual usage of the technology, which is determined by the previous experience of using this technology [20, 75-77]. An integrated theoretical framework that was primarily based on TAM was put forward in this study involving E-learning acceptance and intention to use of university students. The study sought to assess the association between university students' intention to use E-learning and specific attributes like "social influence, perceived enjoyment, self-efficacy, perceived usefulness, and perceived ease of use". In addition, it sought to formulate a general linear structural model of E-learning acceptance of university students, which would have implications for a school manager or an educational practitioner to enhance the adoption of E-learning. Certain descriptive factors of E-learning use and the chosen constructs were also identified.

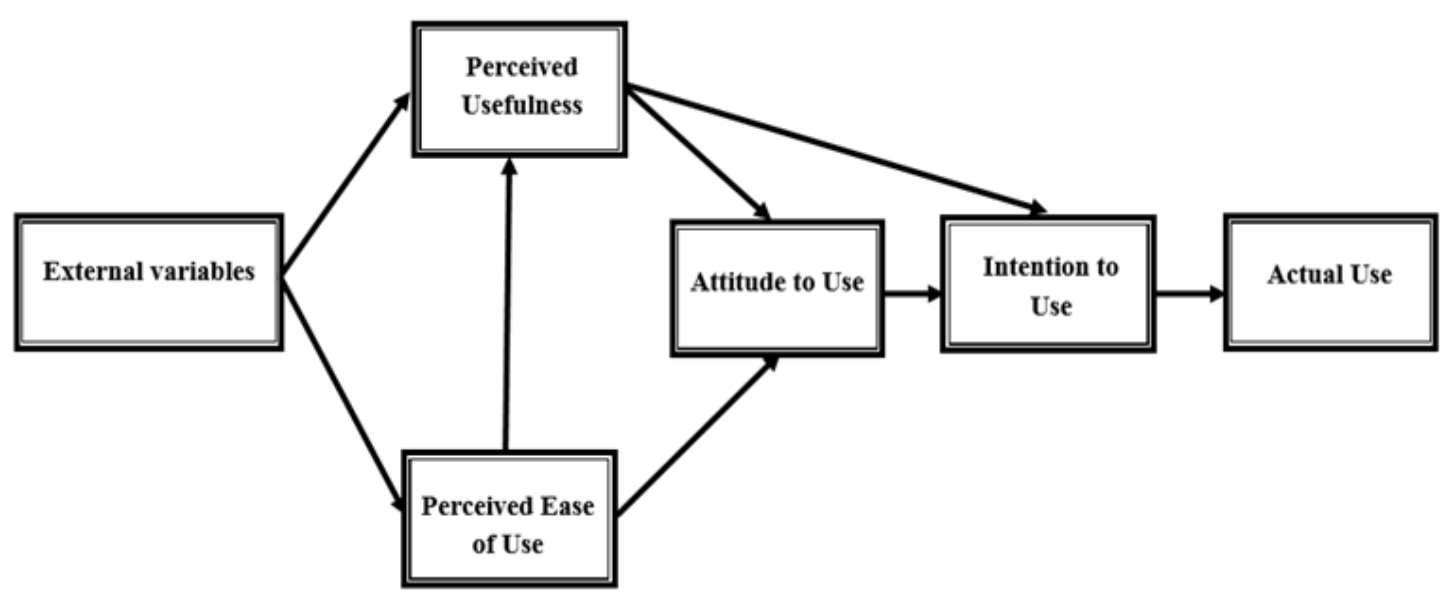

Figure 1. Original version of TAM by [53]

\section{RESEARCH MODEL AND HYPOTHESIS}

Based on TAM, a conceptual model of E-learning technology acceptance was put forward in this study, using previous literature that employed TAM within an educational setting. Furthermore, TAM is expanded in the model by adding further predictor variables, i.e., "Social Influence, Perceived Enjoyment, and Self-efficacy". Figure 2 puts forward the comprehensive conceptual model, while the following sections describe and justify all of the predicted relationships, keeping in view the outcomes of the previous literature.

\subsection{Social influence (SI)}

The social influence refers to "The degree to which an individual perceives that most people who are important to him think he should or should not use the system" [78, 79]. In some situations, a system may be used by people to meet the needs of other people, rather than to concentrate on their own beliefs and feelings [17, 24, 80]. Several studies have been carried out regarding the impact of social influence on the learners' e-learning adoption or acceptance [57, 81-87]. Many studies conducted by many scholars, such as $[17,24,57,83,86-88]$ showed that subjective norm had a significant effect on the perceived usefulness and perceived ease of use of e-learning system. This gives rise to the hypotheses given below:

H1a. Social influence (SI) has a positive influence on perceived usefulness (PU).

H1b. Social influence (SI) has a positive influence on perceived ease of use (PEOU). 


\subsection{Perceived enjoyment (PE)}

Perceived enjoyment (PE) is defined by [58] as "The extent to which the activity of using a specific system is perceived to be enjoyable in its own right, aside from any performance consequences resulting from system use" [89]. Interest has been shown by several researchers in enjoyment involved in the studies pertaining to technology acceptance since the intrinsic variables may have a positive impact on the perspective of users $[57,70,81,84,86,90]$. When a user feels enjoyment while working on a new system, there may be a decline in their perceptions of the effort they are putting in. Therefore, perceived enjoyment signifies a significant factor that describes the adoption or acceptance of e-learning. Earlier studies showed that there is a significant effect of perceived enjoyment [21] on perceived ease of use $[42,57,70,91]$, and perceived usefulness $[42,57,70,86,90,91]$ of e-learning. When students know that they will have an enjoyable experience while working on e-learning systems, there is a greater likelihood that they will have a positive effect on the usefulness and ease of use of such systems [44]. Therefore, the hypotheses given below were formulated:

H2a. Perceived enjoyment (PE) has a positive influence on perceived usefulness (PU).

H2b. Perceived enjoyment (PE) has a positive influence on perceived ease of use (PEOU).

\subsection{Computer self-efficacy (CSE)}

According to [92-94], self-efficacy is "The degree to which an individual believes that he or she has the ability to perform a specific task/job using the computer". Self-efficacy is linked to computer systems in this study (i.e., the confidence shown by the users in their own capacity to employ the e-learning system). It was stated in many studies such as $[57,82-84,88,95,96]$ that computer self-efficacy (CSE) plays a critical role in identifying the emotions and behavior of a person. Hence, it is claimed that when there are high expectations of efficacy, there are greater possibilities of achieving success in a given task. An analysis of the e-learning literature showed that the most extensively used external determinant of TAM was computer self-efficacy. Different empirical studies showed that there was a significant effect of computer self-efficacy on the perceived usefulness, perceived ease of use of the e-learning system [57, 82-84, 88, 95, 96]. Therefore, the hypotheses given below were formulated:

H3a. Computer self-efficacy (CSE) has a positive influence on perceived usefulness (PU).

H3b. Computer self-efficacy (CSE) has a positive influence on perceived ease of use (PEOU).

\subsection{Core TAM constructs}

The adoption of new technology such as mobile technology is facilitated by the perceived usefulness and perceived ease of use $[42,97,98]$. It was stated in the TAM and other relevant studies that these factors have a significant impact on the behavioral intention to use. The user's perspective regarding the ease of understanding helps to a large extent in identifying the potency and the extent to which the user exhibits adaption to new technology [53, 99]. It was shown in a previous study that perceived ease of use (PEOU) has a significant influence on the perceived usefulness [57, 70, 83, 84, 88, 90, 100-104]. Several studies have been carried out in the past that claim that there is a positive association between the perceived ease of use (PEOU) and the behavioral intention to use E-learning system (BI), direct as well indirect [57, 70, 83, 84, 88, 90, 100-104]. According to [105], perceived usefulness (PU) will affect their intention to directly or indirectly agree to and adjust to the E-learning system. In the previous, it has been found that perceived usefulness (PU) has a significant positive relationship with the intention to use the E-learning system (BI) $[57,70,83,84,88,90,96,100-104]$. This research puts forward the hypotheses given below, in accordance with the given literature, in addition to presenting a significant positive association between $\mathrm{BI}, \mathrm{PU}$, and PEOU.

H4. Perceived ease of use (PEOU) has a positive influence on perceived usefulness (PU).

H5. Perceived usefulness (PU) has a positive influence on behavioral intention to use social network technology (ELSA).

H6. Perceived ease of use (PEOU) has a positive influence on behavioral intention to use social network technology (ELSA).

The research model given in Figure 2 has been developed in this research using the hypotheses given above.

\section{RESEARCH METHOD}

\subsection{Procedure}

Data collection was carried out by the postgraduate students at the University of Al Fujairah. The questionnaire is the fundamental tool of data collection, were distributed among the students to validate the various research hypotheses and to determine the impact of factors being researched. The questionnaire included 17 items that were distributed under different factors, including "social influence, perceived 
enjoyment, self-efficacy, perceived ease of use, perceived usefulness, and behavioral intention to use E-learning system". A total of 270 respondents taking part in the research filled the questionnaire.

On the whole, since 30 surveys were uncompleted, the questionnaires were of no use. Therefore, the total number of complete questionnaires were 270 , demonstrating a response rate of $90 \%$. The valid responses that were taken into account and modified into a sample size amounted to 270 responses, according to [106] the estimated sampling size for a population of 460 in 210 respondents. The responses were then examined using the conceptual model. This is acknowledged as a sample size when the structural equation modeling is used for performing the investigation. Therefore, a sample size of 270 is high when compared to the insignificant requirements used for the analysis of the hypotheses in this research [107].

\subsection{Participants}

Once the questionnaires were collected, respondents were classified in accordance with the distinct standards: age, gender, and the use of the E-learning system. The sample size of the study was 270 students, of which 175 were females, and 95 were males (65\% and 35\% respectively). The ages of $68 \%$ of the students were between 18 and 29 . The ages of the rest of the $32 \%$ of the participants were over 30 years. Out of the 270 students, $265(98 \%)$ were believed to highly competent in computer skills. $92 \%$ of the candidates stated that they use the E-learning system every day.

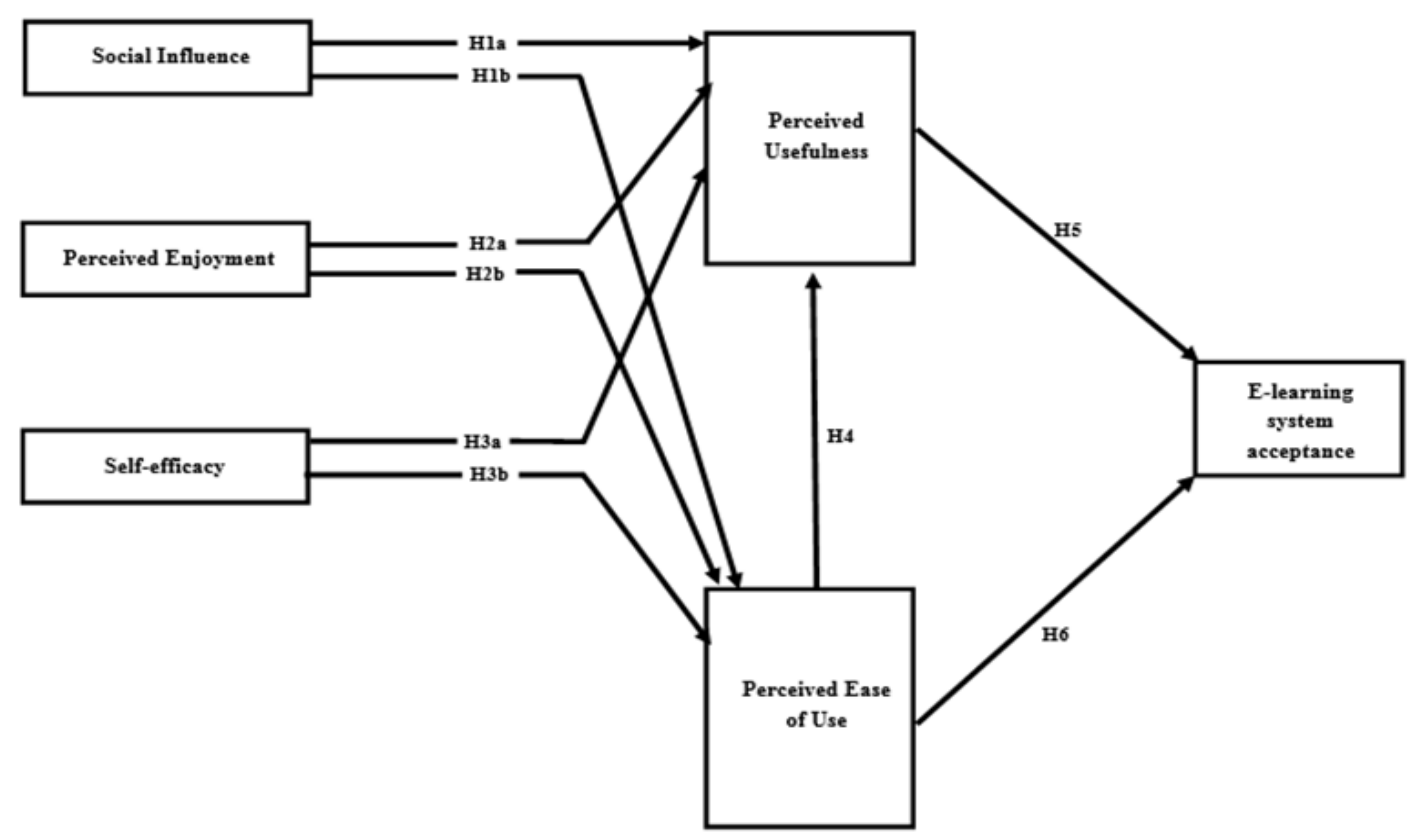

Figure 2. The proposed theoretical model

\section{RESULTS AND DISCUSSIONS}

\subsection{Measurement model analysis}

Before checking for important connections in the structural model, the measurement method must show a reasonable level of reliability and validity [108, 109]. The measurement model is made up of correlations between the latent factors and the variables identified that underlie that construct.

\subsection{Convergent validity}

The Cronbach's alpha scores, as shown in Table 1 , are greater than 0.7 , and the construct's composite reliabilities differ from the range of 0.722 to 0.898 . Therefore, the condition for explicating at least 50 percent of this variance extracted between a set of the elements underlying the latent structure meets all the AVE (Average Variance extracted) values between 0.553 and 0.786 . As a consequence, the convergent validity of the measurements for the constructs of buildings is considered. The following [110] metrics are used as indicators to measure the relative value of convergent validity, which are factors loadings, variance 
extracted, and reliability (consisting of Cronbach's Alpha and composite reliability). For all constructs, the reliability coefficient and composite reliability (CR) surpass 0.7 , for all of the constructs, which shows that ongoing coherence among many dimensions of a construct [111].

Table 1. Convergent validity results which assures acceptable values (factor loading, cronbach's alpha, composite reliability $\geq 0.70$ \& AVE >0.5)

\begin{tabular}{|c|c|c|c|c|c|}
\hline Variables & Item & FL & Cronbach's Alpha & $\mathrm{CR}$ & AVE \\
\hline \multirow{3}{*}{ E-learning system acceptance (ELSA) } & ELSA_1 & 0.766 & \multirow{3}{*}{0.799} & \multirow{3}{*}{0.722} & \multirow{3}{*}{0.745} \\
\hline & ELSA_2 & 0.869 & & & \\
\hline & PEOU_1 & 0.727 & & & \\
\hline \multirow[t]{3}{*}{ Perceived ease of use (PEOU) } & PEOU_2 & 0.799 & \multirow[t]{3}{*}{0.791} & \multirow[t]{3}{*}{0.873} & \multirow[t]{3}{*}{0.591} \\
\hline & PEOU_3 & 0.889 & & & \\
\hline & PE_1 & 0.915 & & & \\
\hline \multirow[t]{3}{*}{ Perceived Enjoyment (PE) } & PE_2 & 0.845 & \multirow[t]{3}{*}{0.878} & \multirow[t]{3}{*}{0.888} & \multirow[t]{3}{*}{0.761} \\
\hline & PE_3 & 0.819 & & & \\
\hline & PU_1 & 0.851 & & & \\
\hline \multirow[t]{3}{*}{ Perceived Usefulness (PU) } & PU_2 & 0.869 & \multirow[t]{3}{*}{0.917} & \multirow[t]{3}{*}{0.898} & \multirow[t]{3}{*}{0.786} \\
\hline & PU_3 & 0.729 & & & \\
\hline & SE_1 & 0.896 & & & \\
\hline \multirow[t]{3}{*}{ Self-efficacy (SE) } & SE_2 & 0.788 & \multirow[t]{3}{*}{0.817} & \multirow[t]{3}{*}{0.844} & \multirow[t]{3}{*}{0.628} \\
\hline & SE_3 & 0.891 & & & \\
\hline & SI_1 & 0.727 & & & \\
\hline \multirow[t]{2}{*}{ Social Influence (SI) } & SI_2 & 0.719 & \multirow{2}{*}{0.717} & \multirow{2}{*}{0.814} & \multirow{2}{*}{0.553} \\
\hline & SI_3 & 0.910 & & & \\
\hline
\end{tabular}

\subsection{Discriminant validity}

As is shown by Table 2 and Table 3, the criteria for discriminant validity have been fulfilled as all the AVE values in the measurement model are larger than their squared correlation, among the constructs [108, 109, 111].

Table 2. Fornell-larcker scale

\begin{tabular}{ccccccc}
\hline & ELSA & PEOU & PE & PU & SE \\
\hline ELSA & 0.844 & & & & \\
PEOU & 0.392 & 0.911 & & & \\
PE & 0.268 & 0.559 & 0.797 & & \\
PU & 0.494 & 0.429 & 0.611 & 0.929 & 0.876 \\
SE & 0.123 & 0.529 & 0.335 & 0.312 & 0.621 \\
SI & 0.102 & 0.529 & 0.246 & 0.414 & 0.808 \\
\hline
\end{tabular}

Note: SI, social influence; PE, perceived enjoyment; SE, self- efficacy; PEOU, perceived ease of use; PU, perceived usefulness; ELSA, E-learning system acceptance.

Table 3. Heterotrait-monotrait ratio (HTMT)

\begin{tabular}{cccccc}
\hline & ELSA & PEOU & PE & PU & SE \\
\hline ELSA & & & & & \\
PEOU & 0.228 & & & & \\
PE & 0.324 & 0.281 & & & \\
PU & 0.466 & 0.232 & 0.519 & & \\
SE & 0.261 & 0.108 & 0.300 & 0.446 & 0.417 \\
SI & 0.026 & 0.204 & 0.528 & 0.641 & \\
\hline
\end{tabular}

Note: SI, social influence; PE, perceived enjoyment; SE, self- efficacy; PEOU, perceived ease of use; PU, perceived usefulness; ELSA, E-learning system acceptance.

\subsection{Structural model analysis (SEM)}

With the final goal to examine the proposed hypotheses, the relationships that the theoretical constructs for the structural model have with each other were assessed via a structural equation model that had SEM-PLS with the maximum likelihood estimation [6, 24, 25, 42, 112-115]. As appeared in Table 4 and Figure 3, the model had a high predictive power [116], that's, the percentage of the variance within perceived usefulness, perceived ease of use, and e-learning system acceptance are nearly $70 \%, 70 \%$, and $71 \%$, separately [117-140]. All hypotheses were found to be significant. Based on the data analysis hypotheses $\mathrm{H} 1 \mathrm{a}, \mathrm{H} 1 \mathrm{~b}, \mathrm{H} 2 \mathrm{a}, \mathrm{H} 2 \mathrm{~b}, \mathrm{H} 3 \mathrm{a}, \mathrm{H} 3 \mathrm{~b}, \mathrm{H} 4, \mathrm{H} 5$, and H6 were supported by the empirical data. The results showed that perceived usefulness (PU) significantly influenced social influence (SI) $(\beta=0.723, P<0.001)$, 
perceived enjoyment $(\mathrm{PE})(\beta=0.277, \mathrm{P}<0.05)$, self-efficacy $(\mathrm{SE})(\beta=0.566, \mathrm{P}<0.001)$, and perceived ease of use $(\mathrm{PEOU})(\beta=0.302, \mathrm{P}<0.05)$ supporting hypothesis $\mathrm{H} 1 \mathrm{a}, \mathrm{H} 2 \mathrm{a}, \mathrm{H} 3 \mathrm{a}$, and $\mathrm{H} 4$ respectively. Perceived ease of use (PEOU) was determined to be significant in affecting social influence (SI) $(\beta=0.424, \mathrm{P}<0.001)$, perceived enjoyment $(\mathrm{PE})(\beta=0.312, \mathrm{P}<0.001)$ and self-efficacy $(\mathrm{SE})(\beta=0.404, \mathrm{P}<0.001)$ supporting hypothesis $\mathrm{H} 1 \mathrm{~b}$, $\mathrm{H} 2 \mathrm{~b}$, and $\mathrm{H} 3 \mathrm{~b}$ respectively. Furthermore, E-learning system acceptance (ELSA) was significantly influenced by perceived usefulness (PU) $(\beta=0.256, \mathrm{P}<\mathrm{P}<0.001)$ and perceived ease of use (PEOU) $(\beta=0.519, \mathrm{P}<$ $\mathrm{P}<0.05)$ which support hypotheses H5 and H6. A summary of the hypotheses testing results is shown in Table 5 .

Table 4. $\mathrm{R}^{2}$ of the endogenous latent variables

\begin{tabular}{ccc}
\hline Constructs & $\mathrm{R}^{2}$ & Results \\
\hline PU & 0.694 & High \\
PEOU & 0.703 & High \\
ELSA & 0.714 & High \\
\hline Note: PU, perceived usefulness; & PEOU, perceived ease of use; ELSA, E-learning \\
system acceptance.
\end{tabular}

External variables

Technology Acceptance Model (TAM)

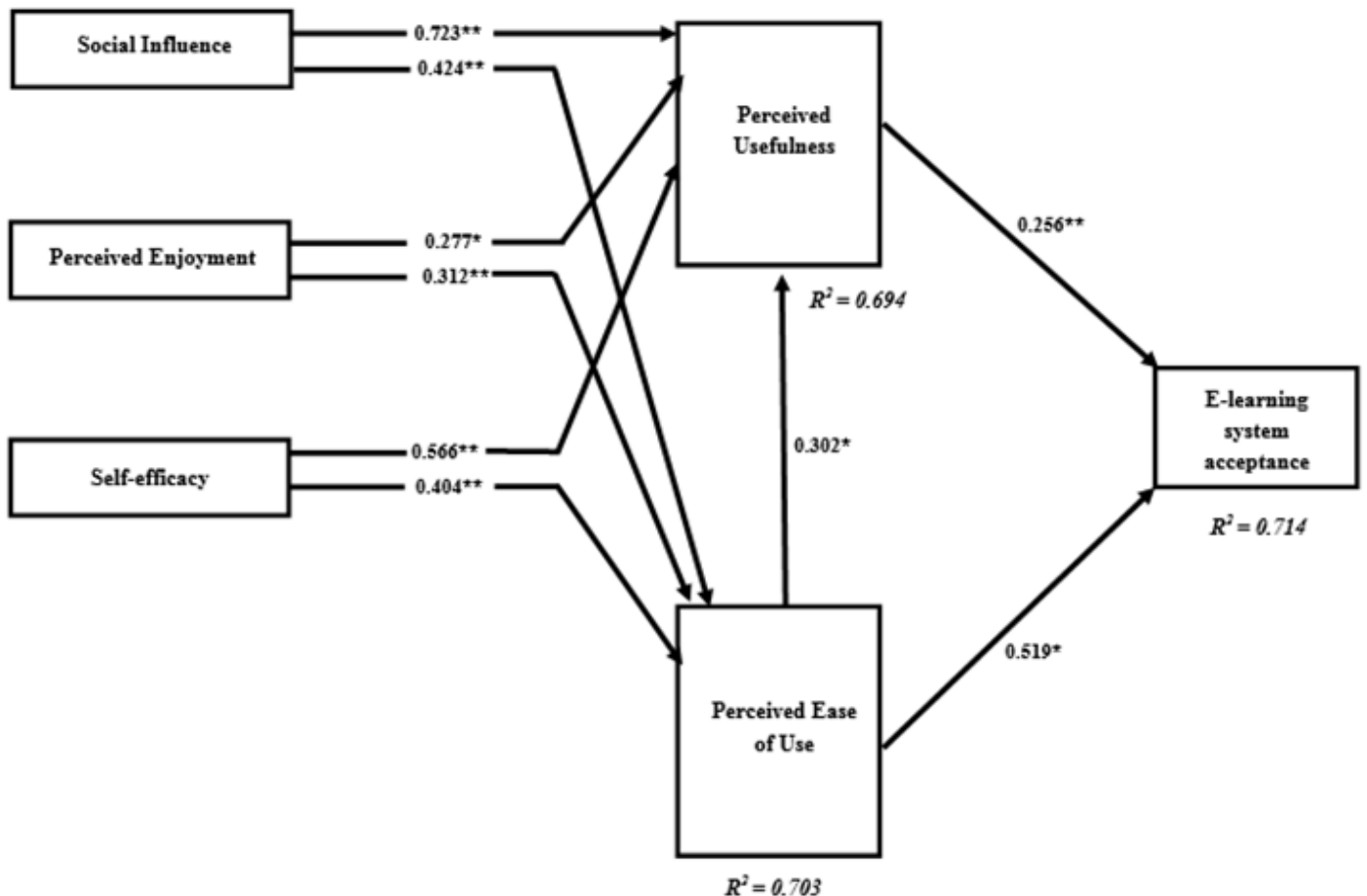

Figure 3. Result of the research model

Table 5. Hypotheses of the study

\begin{tabular}{|c|c|c|c|c|c|c|}
\hline HYP. & REL. & PATH & T_VAL & P_VAL & DIR. & DES. \\
\hline H1a & SI-> PU & 0.723 & 22.271 & 0.000 & Positive & Supported** \\
\hline $\mathrm{H} 1 \mathrm{~b}$ & SI -> PEOU & 0.424 & 19.539 & 0.000 & Positive & Supported** \\
\hline $\mathrm{H} 2 \mathrm{a}$ & $\mathrm{PE}->\mathrm{PU}$ & 0.277 & 1.850 & 0.031 & Positive & Supported* \\
\hline $\mathrm{H} 2 \mathrm{~b}$ & $\mathrm{PE}->\mathrm{PEOU}$ & 0.312 & 8.891 & 0.003 & Positive & Supported** \\
\hline $\mathrm{H} 3 \mathrm{a}$ & SE -> PU & 0.566 & 15.404 & 0.000 & Positive & Supported** \\
\hline $\mathrm{H} 3 \mathrm{~b}$ & SE -> PEOU & 0.404 & 8.329 & 0.004 & Positive & Supported** \\
\hline $\mathrm{H} 4$ & PEOU -> PU & 0.302 & 2.133 & 0.011 & Positive & Supported* \\
\hline H5 & PU $->$ ELSA & 0.256 & 17.459 & 0.000 & Positive & Supported** \\
\hline H6 & PEOU -> ELSA & 0.519 & 6.426 & 0.021 & Positive & Supported* \\
\hline
\end{tabular}

Note: *p < 0.05; **p < 0.01 SI, social influence; PE, perceived enjoyment; SE, self- efficacy; PEOU, perceived ease of use; PU, perceived usefulness; ELSA, E-learning system acceptance. 


\section{CONCLUSION}

The objective of this research is to extract the critical factors associated with E-learning acceptance or adoption within the UAE. The critical factors were subjected to a statistical analysis which showed social influence (SI), perceived enjoyment (PE), and computer self-efficacy (SE) maintain a positive and strong effect upon, perceived ease of use (PEOU) and perceived usefulness (PU). Additionally, behavioral intention to use the E-learning system (ELSA) is being significantly affected by the perceived usefulness (PU) and perceived ease of use (PEOU). Various other research studies assessed the positive influence of social influence, perceived enjoyment, and computer self-efficacy on perceived ease of use, perceived usefulness, and E-learning acceptance. The administration at the university is engaged in creating an E-learning infrastructure and to carry out assessments. The research is engaged in extracting and analyzing the learner perspectives influential factors keeping in mind the acceptance and adoption of E-learning systems. Thorough information can be gained through external factor research results. The recommendations and the information can be shared with practitioners, developers, policymakers, and designers so that they may effectively adopt the e-learning systems.

The research model presents a framework that can be used by the university administration so that they may create the E-learning infrastructure and analyze the readability of the students. When the E-learning practice is being planned or evaluated, the online platforms and university administration should consider these factors. The social factors are also significant which are related to the students' adoption of E-learning and they have been presented as part of the research outcomes. Furthermore, the E-learning culture should be deployed so that the entire E-learning process is understood and the E-learning adoption is supported. This culture should be present within the student community, the readability of the students towards E-learning must be developed and evaluated, students should be provided with internet access free of cost and a server should be of high capabilities, the computer labs should be built using appropriate E-learning facilities and all university students should be able to access these facilities throughout the day. Furthermore, it is possible to strengthen E-learning through planning and to carry out events and implementing an E-learning culture amongst the students and relatives. The positive attitude towards E-learning can also be developed by conducting training courses as it would help state E-learning usefulness and ease perceptions. Hence, E-learning is practiced efficiently only after enhancing behavioral intention.

A strict research process is being followed within this research, but there is a specific limitation that needs to be considered so that future research can benefit. The response rate attained from the students was quite low. The research results have been extracted using the UAE population, which makes use of the E-learning systems. Hence, when generalizing the results, the cross-cultural difference amongst provinces should be kept in mind. The research also analyzed the intention of the learners to adopt the E-learning systems, and much importance has also been given to the role played by the faculty in stating the adoption intention. Future studies would indicate the role played by the faculty for E-learning system adoption.

\section{REFERENCES}

[1] S. A. Salloum and K. Shaalan, "Factors affecting students' acceptance of e-learning system in higher education using UTAUT and structural equation modeling approaches," in International Conference on Advanced Intelligent Systems and Informatics, pp. 469-480, 2018.

[2] R. S. Al-Maroof, et al., "Understanding an Extension Technology Acceptance Model of Google Translation: A Multi-Cultural Study in United Arab Emirates," International Journal of Interactive Mobile Technologies, vol. 14, no. 03, pp. 157-178, 2020.

[3] B. A. Kurdi, et al., "An empirical investigation into examination of factors influencing university students' behavior towards elearning acceptance using SEM approach," International Journal of Interactive Mobile Technologies, vol. 14, no. 2, pp. 19-41, 2020.

[4] K. Martin, "Self-efficacy as an evaluation measure for programs in support of online learning literacies for undergraduates," Internet and Higher Education, vol. 8, no. 4, pp. 307-322, 2005.

[5] Al-Maroof, R. S., \& Salloum, S. A., "An Integrated Model of Continuous Intention to Use of Google Classroom," In Recent Advances in Intelligent Systems and Smart Applications, Springer, Cham pp. 311-335, 2020.

[6] M. Alshurideh, et al., "Factors affecting the Social Networks Acceptance: An Empirical Study using PLS-SEM Approach," in 8th International Conference on Software and Computer Applications, pp. 414-418, 2019.

[7] N. Li and G. Kirkup, "Gender and cultural differences in Internet use: A study of China and the UK," Computer and Education, vol. 48, no. 2, pp. 301-317, 2007.

[8] A. Tarhini, et al., "Factors affecting students' acceptance of e-learning environments in developing countries: a structural equation modeling approach," International Journal of Information and Education Technology, vol. 3, no. 1 , pp. 54-59, 2013.

[9] A. Tarhini, et al., "The effects of individual differences on e-learning users' behaviour in developing countries: A structural equation model," Computer in Human Behavior, vol. 41, pp. 153-163, 2014.

[10] S. A. Salloum, et al., "Factors affecting the E-learning acceptance: A case study from UAE," Education and Information Technologies, vol 24, no. 1, pp. 509-530, 2019. 
[11] S. A. Salloum and K. Shaalan, "Adoption of e-book for university students," in International Conference on Advanced Intelligent Systems and Informatics, pp. 481-494, 2018.

[12] S. A. Salloum, et al., "Machine Learning and Deep Learning Techniques for Cybersecurity: A Review," in Joint European-US Workshop on Applications of Invariance in Computer Vision, pp. 50-57, 2020.

[13] A. Y. Zainal, et al., "Dimensions of Agility Capabilities Organizational Competitiveness in Sustaining," in Joint European-US Workshop on Applications of Invariance in Computer Vision, pp. 762-772, 2020.

[14] S. A. Salloum, et al., "A Survey of Semantic Analysis Approaches," in Joint European-US Workshop on Applications of Invariance in Computer Vision, pp. 61-70, 2020.

[15] S. A. Salloum, et al., "Mining in Educational Data: Review and Future Directions," in Joint European-US Workshop on Applications of Invariance in Computer Vision, pp. 92-102, 2020.

[16] K. Kim and J. Moore, "Web-based learning: Factors affecting students' satisfaction and learning experience," First Monday, vol. 10, no. 11, 2005.

[17] Al-Maroof, R. A., Arpaci, I., Al-Emran, M., Salloum, S. A., \& Shaalan, K., "Examining the Acceptance of WhatsApp Stickers Through Machine Learning Algorithms," In Recent Advances in Intelligent Systems and Smart Applications, Springer, Cham, pp. 209-221, 2020.

[18] S. Zhang, et al., "Extending TAM for online learning systems: An intrinsic motivation perspective," Tsinghua Science and Technology, vol. 13, no. 3, pp. 312-317, 2008

[19] G. Walker and N. Johnson, "Faculty intentions to use components for web-enhanced instruction," International Journal on E-learning, vol. 7, no. 1, pp. 133-152, 2008.

[20] M. Alshurideh, et al., "Examining the Main Mobile Learning System Drivers' Effects: A Mix Empirical Examination of Both the Expectation-Confirmation Model (ECM) and the Technology Acceptance Model (TAM)," in International Conference on Advanced Intelligent Systems and Informatics, pp. 406-417, 2019.

[21] S. A. S. Salloum and K. Shaalan, "Investigating students' acceptance of E-learning system in Higher Educational Environments in the UAE: Applying the Extended Technology Acceptance Model (TAM)," The British University in Dubai, 2018.

[22] S. McCoy, et al., "Integrating national culture into IS research: The need for current individual level measures," Communications of the Association for Information System, vol. 15, no. 1, pp. 211-224, 2005.

[23] D. Straub, et al., "Testing the technology acceptance model across cultures: A three country study," Information and Management, vol. 33, no. 1, pp. 1-11, 1997.

[24] S. A. Salloum, et al., "Exploring Students' Acceptance of E-Learning Through the Development of a Comprehensive Technology Acceptance Model," IEEE Access, vol. 7, pp. 128445-128462, 2019.

[25] S. A. Salloum, et al., "An Innovative Study of E-Payment Systems Adoption in Higher Education: Theoretical Constructs and Empirical Analysis," Intenational Journal of Interactive Mobile Technologies, vol. 13, no. 6, pp. 68-83, 2019.

[26] G. Chadha and K. S. M. Nafay, "E-Learning: An expression of the knowledge economy," McGraw-Hill, Inc., 2003.

[27] D. U. Vidanagama, "Acceptance of E-Learning among Undergraduates of Computing Degrees in Sri Lanka," International Journal of Modern Education and Computer Science, vol. 8, no. 4, pp. 25-32, 2016.

[28] J. C. Evans, et al., "Blended learning in higher education: professional development in a Hong Kong university," Higher Education Research and Development, vol. 39, no. 4, pp. 643-656, 2020.

[29] M. J. Rosenberg and R. Foshay, "E-learning: Strategies for delivering knowledge in the digital age," Performance Improvement, vol. 41, no. 5, pp. 50-51, 2002.

[30] I. Roffe, "E-learning: engagement, enhancement and execution," Quality Assurance in Education, vol. 10, no. 1, pp. 40-50, 2002.

[31] E. T. Welsh, et al., "E-learning: emerging uses, empirical results and future directions," International Journal of Training and Development, vol. 7, no. 4, pp. 245-258, 2003.

[32] R. Watkins, "75 E-learning activities: Making online learning interactive," Pfeiffer San Francisco, 2005.

[33] D. Gonzalez, "Teaching and learning through chat: A taxonomy of educational chat for EFL/ESL," Teaching English with Technology, vol. 3, no. 4, pp. 57-69, 2003.

[34] A. Kokane, et al., "Effective e-learning using 3D virtual tutors and WebRTC based multimedia chat," in 2014 International Conference on Recent Trends in Information Technology, pp. 1-6, 2014.

[35] S. Aloraini, "The impact of using multimedia on students' academic achievement in the College of Education at King Saud University,” Journal of King Saud University - Language and Translation, vol. 24, no. 2, pp. 75-82, 2012 .

[36] E. Webb, et al., "Using e-learning dialogues in higher education," Innovations on Education and Teaching International, vol. 41, no. 1, pp. 93-103, 2004.

[37] R. Raitman, et al., "Employing wikis for online collaboration in the e-learning environment: Case study," in Third International Conference on Information Technology and Applications (ICITA'05), vol. 2, pp. 142-146, 2005.

[38] N. Augar, et al., "Teaching and learning online with wikis," in Beyond the comfort zone: proceedings of the 21st ASCILITE Conference, Perth, pp. 95-104, 2004.

[39] L. A. Abdillah, "Students learning center strategy based on e-learning and blogs," arXiv Prepr. arXiv1307.7202, 2013.

[40] L. Armstrong, et al., "Blogs as electronic learning journals," E-Journal Instructional Science and Technology, vol. 7, no. 1, 2004.

[41] D. S. Priyangika and C. Chiran, "IT students' perceptions on e-learning: a preliminary survey at University of Colombo," Journal of the University Librarians Association, Sri Lanka, vol. 16, no. 2, pp. 160-178, 2012. 
[42] M. T. Alshurideh, et al., "Understanding the Quality Determinants that Influence the Intention to Use the Mobile Learning Platforms: A Practical Study," International Journal of Interactive Mobile Technologies, vol. 13, no. 11, pp. 157-183, 2019.

[43] S. K. Sharma and J. K. Chandel, "Technology acceptance model for the use of learning through websites among students in Oman," International Arab Journal of E-learning, vol. 3, no. 1, pp. 44-49, 2013.

[44] H. Van der Heijden, "User acceptance of hedonic information systems," MIS Quarterly, vol. 28, no. 4, pp. 695-704, 2004.

[45] F. D. Davis, "Perceived Usefulness, Perceived Ease of Use, and User Acceptance of Information Technology," MIS Quarterly, vol. 13, no. 3, pp. 319-340, 1989.

[46] V. Venkatesh and H. Bala, "Technology Acceptance Model 3 and a Research Agenda on Interventions," Decision Sciences, vol. 39, no. 2, pp. 273-315, 2008.

[47] S. H. Alshammari, et al., "The Influences of Technical Support, Self Efficacy and Instructional Design on the Usage and Acceptance of LMS: A Comprehensive Review," Turkish Online Journal of Educational Technology, vol. 15, no. 2, pp. 116-125, 2016.

[48] M. Al-Emran, et al., "An empirical examination of continuous intention to use m-learning: An integrated model," Education and Information Technologies, pp. 1-20, 2020.

[49] A. Haddad, et al., "The Impact of Technology Readiness on the Big Data Adoption Among UAE Organisations," in Data Management, Analytics and Innovation, pp. 249-264, 2020.

[50] J. R. Hauser and S. M. Shugan, "Intensity measures of consumer preference," Operations Research, vol. 28, no. 2, pp. 278-320, 1980.

[51] D. F. Larcker and V. P. Lessig, "Perceived usefulness of information: A psychometric examination," Decision Science, vol. 11, no. 1, pp. 121-134, 1980.

[52] A. Dillon and M. G. Morris, "User acceptance of new information technology: theories and models," Medford, NJ, Information Today, 1996.

[53] F. D. Davis, "Perceived usefulness, perceived ease of use, and user acceptance of information technology," MIS Quarterly, pp. 319-340, 1989.

[54] T. Abbas and T. Abbas, "Social factors affecting students' acceptance of e-learning environments in developing and developed countries: A structural equation modeling approach," Journal of Hospitality and Tourism Technology, vol. 7, no. 2, pp. 200-212, 2016.

[55] T. M. Abbas, "Human factors affecting university hospitality and tourism students' intention to use e-learning: A comparative study between Egypt and the UK," Journal of Human Resources in Hospitality and Tourism, vol. 16, no. 4, pp. 349-366, 2017.

[56] T. M. Abbas, et al., "Technological Factors Influencing University Tourism and Hospitality Students' Intention to Use E-Learning: A Comparative Analysis of Egypt and the United Kingdom," Journal of Hospitality and Tourism Education, vol. 28, no. 4, pp. 189-201, 2016.

[57] S. S. Al-Gahtani, "Empirical investigation of e-learning acceptance and assimilation: A structural equation model," Applied Computing and Informatics, vol. 12, no. 1, pp. 27-50, 2016.

[58] S. Alharbi and S. Drew, "Using the technology acceptance model in understanding academics' behavioural intention to use learning management systems," International Journal of Advanced Computer Science and Applications, vol. 5, no. 1, pp. 143-155, 2014.

[59] M. M. Alkharang, "Factors that influence the adoption of e-learning: an empirical study in Kuwait," Brunel University London, 2014.

[60] M. A. Almaiah, et al., "Extending the TAM to examine the effects of quality features on mobile learning acceptance," Journal of Computers in Education, vol. 3, no. 4, pp. 453-485, 2016.

[61] D. Al-Fraihat, et al., "Evaluating E-learning systems success: An empirical study," Computers in Human Behavior, vol. 102, pp. 67-86, 2020.

[62] M. S. Taat and A. Francis, "Factors Influencing the Students' Acceptance of E-Learning at Teacher Education Institute: An Exploratory Study in Malaysia," International Journal of Higher Education, vol. 9, no. 1, pp. 133-141, 2020.

[63] N. F. A. Al-Mushasha, "Determinants of e-learning acceptance in higher education environment based on extended technology acceptance model," in 2013 Fourth International Conference on e-Learning Best Practices in Management, Design and Development of e-Courses: Standards of Excellence and Creativity, pp. 261-266, 2013.

[64] S. A. Salloum, et al., "Understanding the Impact of Social Media Practices on E-Learning Systems Acceptance," International Conference on Advanced Intelligent Systems and Informatics, pp. 360-369, 2020.

[65] A. Y. Alsabawy, et al., "Determinants of perceived usefulness of e-learning systems," Computers in Human Behavior, vol. 64, pp. 843-858, 2016.

[66] R. A. Sánchez, et al., "E-learning and the University of Huelva: a study of WebCT and the technological acceptance model," Campus-Wide Information Systems, vol. 30, no. 2, pp. 135-160, 2013.

[67] S. O. Ayodele, et al., "Role of power supply towards e-learning acceptance: VBSEM-AMOS," in International Conference on Information Communication and Management (ICICM), pp. 151-155, 2016.

[68] F. A. Bachtiar, et al., "Acceptance in the deployment of blended learning as a learning resource in information technology and computer science program, Brawijaya university," in 2014 Asia-Pacific Conference on Computer Aided System Engineering (APCASE), pp. 131-135, 2014.

[69] R. Boateng, et al., "Determinants of e-learning adoption among students of developing countries," International Journal of Information and Learning Technology, vol. 33, no. 4, pp. 248-262, 2016. 
[70] C. T. Chang, et al., "Examining the students' behavioral intention to use e-learning in Azerbaijan? The General Extended Technology Acceptance Model for E-learning approach," Computers and Education, vol. 111, pp. 128-143, 2017.

[71] T. H. Chu and Y. Y. Chen, "With Good We Become Good: Understanding e-learning adoption by theory of planned behavior and group influences," Computers and Education, vol. 92, pp. 37-52, 2016.

[72] S. A. Salloum, et al., "Understanding the Impact of Social Media Practices on E-Learning Systems Acceptance," in International Conference on Advanced Intelligent Systems and Informatics, pp. 360-369, 2019.

[73] L. N. Proffitt, "A study of the influence of learner readiness on academic success and student perceptions of online learning," Dissertation, Capella University, 2008.

[74] D. Shen, et al., "Social influence for perceived usefulness and ease-of-use of course delivery systems," Journal of Interactive Online Learning, vol. 5, no. 3, pp. 270-282, 2006.

[75] T. Farahat, "Applying the technology acceptance model to online learning in the Egyptian universities," Procedia Social Behavior Science, vol. 64, pp. 95-104, 2012.

[76] M. Alshurideh, et al., "The Effect of Previous Experience on Mobile Subscribers' Repeat Purchase Behaviour," European Journal of Social Sciences, vol. 30, no. 3, pp. 366-376, 2012.

[77] B. Šumak, et al., "Factors affecting acceptance and use of Moodle: An empirical study based on TAM," Informatica, vol. 35, no. 1, pp. 91-100, 2011.

[78] M. Fishbein and I. Ajzen, "Belief, attitude, intention and behavior: An introduction to theory and research," Addison-Wesley, 1975.

[79] V. Venkatesh, et al., "User acceptance of information technology: Toward a unified view," MIS Quarterly, pp. 425-478, 2003.

[80] A. R. Alenezi, et al., "Institutional support and e-learning acceptance: An extension of the technology acceptance model," International Journal of Instructional Technology and Distance Learning, vol. 8, no. 2, pp. 3-16, 2011.

[81] F. Kanwal and M. Rehman, "Factors Affecting E-Learning Adoption in Developing Countries-Empirical Evidence from Pakistan's Higher Education Sector,” IEEE Access, vol. 5, pp. 10968-10978, 2017.

[82] Y. C. Lee, "An empirical investigation into factors influencing the adoption of an e-learning system," Online Information Review, vol. 30, no. 5, pp. 517-541, 2006.

[83] H. Motaghian, et al., "Factors affecting university instructors' adoption of web-based learning systems: Case study of Iran," Computers and Education, vol. 61, pp. 158-167, 2013.

[84] S. Y. Park, "An analysis of the technology acceptance model in understanding university students' behavioral intention to use e-learning," Journal of. Educational Technology and Society, vol. 12, no. 3, pp. 150-162, 2009.

[85] S. Y. Park, et al., "University students' behavioral intention to use mobile learning: Evaluating the technology acceptance model," British Journal of Educational Technology, vol. 43, no. 4, pp. 592-605, 2012.

[86] A. A. Rabaa'i, "Extending the Technology Acceptance Model (TAM) to assess Students' Behavioural Intentions to adopt an e-Learning System: The Case of Moodle as a Learning Tool," Journal of Emerging Trends in Engineering and Applied Sciences, vol. 7, no. 1, pp. 13-30, 1975.

[87] T. Teo, "Examining the influence of subjective norm and facilitating conditions on the intention to use technology among pre-service teachers: a structural equation modeling of an extended technology acceptance model," Asia Pacific Education Review, vol. 11, no. 2, pp. 253-262, 2010.

[88] M. Abbad, et al., "Students' Decisions to Use an eLearning System: A Structural Equation Modelling Analysis," International Journal of Emerging Technologies in Learning, vol. 4, no. 4, pp. 4-13, 2009.

[89] V. Venkatesh, "Determinants of perceived ease of use: Integrating control, intrinsic motivation, and emotion into the technology acceptance model," Information Systems Research, vol. 11, no. 4, pp. 342-365, 2000.

[90] M. R. M. Torres, et al., "A technological acceptance of e-learning tools used in practical and laboratory teaching, according to the European higher education area," Behavior and Information Technology, vol. 27, no. 6, pp. 495-505, 2008.

[91] A. M. Elkaseh, et al., "The Acceptance of e-learning as a tool for teaching and learning in Libyan higher education," IPASJ International Journal of Information Technology, vol. 3, no. 4, pp. 1-11, 2015.

[92] E. Adewole-Odeshi, "Attitude of Students Towards E-learning in South-West Nigerian Universities: An Application of Technology Acceptance Model," Library Philosophy and Practice, 2014.

[93] D. R. Compeau and C. A. Higgins, "Application of social cognitive theory to training for computer skills," Information Systems Research, vol. 6, no. 2, pp. 118-143, 1995.

[94] D. R. Compeau and C. A. Higgins, "Computer self-efficacy: Development of a measure and initial test," MIS Quarterly, pp. 189-211, 1995.

[95] A. H. Tseng and J. W. Hsia, "The impact of internal locus of control on perceived usefulness and perceived ease of use in e-learning: An extension of the technology acceptance model," in 2008 International Conference on Cyberworlds, pp. 815-819, 2008.

[96] Y. C. Lin, et al., "Understanding college students' continuing intentions to use multimedia e-learning systems," World Transactions on Engneering and Technology Education, vol. 8, no. 4, pp. 488-493, 2010.

[97] M. T. Alshurideh, "A theoretical perspective of contract and contractual customer-supplier relationship in the mobile phone service sector," International Journal of Business and Management, vol. 12, no. 7, pp. 201-210, 2017.

[98] M. T. Alshurideh, "Exploring the main factors affecting consumer choice of mobile phone service provider contracts," International Journal of Communications Network and Systems Sciences, vol. 9, no. 12, pp. 563-581, 2016. 
[99] V. Venkatesh and H. Bala, "Technology acceptance model 3 and a research agenda on interventions," Decision Sciences, vol. 39, no. 2, pp. 273-315, 2008.

[100] J. Zhao and W. Tan, "E-learning systems adoption across cultures: a comparison study," in 2010 International Conference on E-Product E-Service and E-Entertainment (ICEEE), pp. 1-4, 2010.

[101] Y. Cheng, "Antecedents and consequences of e-learning acceptance," Information Systems Journal, vol. 21, no. 3, pp. 269-299, 2011.

[102] R. Cheung and D. Vogel, "Predicting user acceptance of collaborative technologies: An extension of the technology acceptance model for e-learning," Computers and Education, vol. 63, pp. 160-175, 2013.

[103] J. W. Hsia and A. H. Tseng, "An enhanced technology acceptance model for e-learning systems in high-tech companies in Taiwan: analyzed by structural equation modeling," in 2008 International Conference on Cyberworlds, pp. 39-44, 2008.

[104] K. M. Y. Law, et al., "Learning motivation in e-learning facilitated computer programming courses," Computers and Education, vol. 55, no. 1, pp. 218-228, 2010.

[105] C. L. Wang, et al., "Consumer decision-making styles on domestic and imported brand clothing," European Journal of Marketing, vol. 38, no. 1/2, pp. 239-252, 2004.

[106] R. V. Krejcie and D. W. Morgan, "Determining sample size for research activities," Educational and Psychological Measurement, vol. 30, no. 3, pp. 607-610, 1970.

[107] C. L. Chuan and J. Penyelidikan, "Sample size estimation using Krejcie and Morgan and Cohen statistical power analysis: A comparison," Jurnal Penyelidikan IPBL, vol. 7, pp. 78-86, 2006.

[108] C. Fornell and D. F. Larcker, "Evaluating Structural Equation Models With Unobservable Variables and Measurement Error," Journal of Marketing Research, vol. 18, no. 1, pp. 39-50, 1981.

[109] P. Ifinedo, "Acceptance and Continuance Intention of Web-based Learning Technologies (WLT) Use among University Students in a Baltic Country," Electronic Journal of Information Systems in Developing Countries, vol. 23, no. 1, pp. 1-20, 2006.

[110] J. F. Hair, et al, "Multivariate Data Analysis," New York, NY, Macmillan, 1987.

[111] B. Hair, et al., "Tatham, Multivariate data analysis," New Jersey, Pearson Education, 2006.

[112] R. S. Al-Maroof, et al., "A Unified Model for the Use and Acceptance of Stickers in Social Media Messaging," in International Conference on Advanced Intelligent Systems and Informatics, pp. 370-381, 2019.

[113] S. F. S. Alhashmi, et al., "Critical Success Factors for Implementing Artificial Intelligence (AI) Projects in Dubai Government United Arab Emirates (UAE) Health Sector: Applying the Extended Technology Acceptance Model (TAM)," in International Conference on Advanced Intelligent Systems and Informatics, pp. 393-405, 2019.

[114] K. M. Alomari, et al., "Prediction of the Digital Game Rating Systems based on the ESRB," Opcion, vol. 35, no. 19, pp. 1368-1393, 2019.

[115] M. Alshurideh, "Pharmaceutical Promotion Tools Effect on Physician's Adoption of Medicine Prescribing: Evidence from Jordan," Modern Applied Science, vol. 12, no. 11, p. 210, 2018.

[116] W. W. Chin, "The partial least squares approach to structural equation modeling," Modern methods for Business Research, vol. 295, no. 2, pp. 295-336, 1998.

[117] T. Teo and M. Zhou, "The influence of teachers' conceptions of teaching and learning on their technology acceptance," Interactive Learning Environments, vol. 25, no. 4, pp. 513-527, 2017.

[118] J. H. Al-Ammary, et al., "The acceptance of social networking as a learning tools at University of Bahrain," International Journal of Information and Communication Technology Education, vol. 4, no. 2, pp. 208, 2014.

[119] A. Alia, "An investigation of the application of the Technology Acceptance Model (TAM) to evaluate instructors' perspectives on E-Learning at Kuwait University," Dublin City University, 2016.

[120] A. Revythi and N. Tselios, "Extension of Technology Acceptance Model by using System Usability Scale to assess behavioral intention to use e-learning," arXiv Prepr. arXiv1704.06127, 2017.

[121] C. Yi-Cheng, et al., "Predicting college student'use of e-learning systems: an attempt to extend technology acceptance model," PACIS 2007 Proceedings, p. 121, 2007.

[122] M. Chow, et al., "Extending the technology acceptance model to explore the intention to use Second Life for enhancing healthcare education," Computers and Education, vol. 59, no. 4, pp. 1136-1144, 2012.

[123] N. Fathema, et al., "Expanding The Technology Acceptance Model (TAM) to Examine Faculty Use of Learning Management Systems (LMSs) In Higher Education Institutions," Journal of Online Learning and Teaching, vol. 11, no. 2, pp. 210-232, 2015.

[124] Y. H. Lee, et al., "A model of organizational employees'e-learning systems acceptance," Knowledge-based Systems, vol. 24, no. 3, pp. 355-366, 2011.

[125] P. E. Ramírez-Correa, et al., "Gender and acceptance of E-learning: a multi-group analysis based on a structural equation model among college students in Chile and Spain," PLoS One, vol. 10, no. 10, pp. e0140460, 2015.

[126] S. H. Liu, et al., "Applying the technology acceptance model and flow theory to online e-learning users' acceptance behavior," E-learning, vol. 4, pp. H6-H8, 2005.

[127] I. Akman and C. Turhan, "User acceptance of social learning systems in higher education: an application of the extended Technology Acceptance Model," Innovations in Education and Teaching International, vol. 54, no. 3, pp. 229-237, 2017.

[128] H. Haryanto and H. U. Kultsum, "E-Learning Program Adoption: Technology Acceptance Model Approach," in Proceeding of the International Conference on Teacher Training and Education, vol. 2, no. 1, pp. 616-622, 2016.

[129] A. Tarhini, et al., "Towards the Acceptance of RSS to Support Learning: An empirical study to validate the Technology Acceptance Model in Lebanon,” Electronic Journal e-Learning, vol. 13, no. 1, pp. 30-41, 2015. 
[130] A. Al-Adwan, et al., "Exploring students acceptance of e-learning using Technology Acceptance Model in Jordanian universities," International Journal of Education and Development Using Information and Communication Technology, vol. 9, no. 2, pp. 4-18, 2013.

[131] S. A. Saaid and J. A. Rashid, "Interoperability of e-publishing: Knowledge and perception of iLearn system among students," in International Conference on Education and e-Learning (EeL), pp. 184, 2012.

[132] C. H. Ku, "Extending the technology acceptance model using perceived user resources in higher education web-based online learning courses," University of Central Florida, 2009.

[133] M. L. L. Jung, et al., "E-Learning: Investigating University Student s Acceptance of Technology," European Journal of Open, Distance and E-learning, vol. 11, no. 2, pp. 1-9, 2008.

[134] M. Masrom, "Technology acceptance model and e-learning," Technology, vol. 21, no. 24, p. 81, 2007.

[135] A. Tarhini, et al., "Examining the moderating effect of individual-level cultural values on users' acceptance of E-learning in developing countries: a structural equation modeling of an extended technology acceptance model," Interactive Learning Environment, vol. 25, no. 3, pp. 306-328, 2017.

[136] W. Wongvilaisakul and S. Lekcharoen, "The acceptance of e-Learning using SEM approach: A case of IT Literacy development for PIM students," in 2015 12th International Conference on Electrical Engineering/Electronics, Computer, Telecommunications and Information Technology (ECTI-CON), pp. 1-6, 2015.

[137] E. T. Khor, "An analysis of ODL student perception and adoption behavior using the technology acceptance model," International Review of Research in Open and Distance. Learning, vol. 15, no. 6, pp. 275-288, 2014.

[138] K. A. Al-Busaidi, "An empirical investigation linking learners' adoption of blended learning to their intention of full e-learning," Behaviora and Information Technology, vol. 32, no. 11, pp. 1168-1176, 2013.

[139] G. W. H. Tan, et al., "Determinants of mobile learning adoption: An empirical analysis," Journal of Computer Information Systems, vol. 52, no. 3, pp. 82-91, 2012.

[140] Y. L. Theng, et al., "An empirical study of students' perceptions on e-learning systems," in Proceedings of the 2nd International Convention on Rehabilitation Engineering \& Assistive Technology, pp. 245-249, 2008.

\section{BIOGRAPHIES OF AUTHORS}

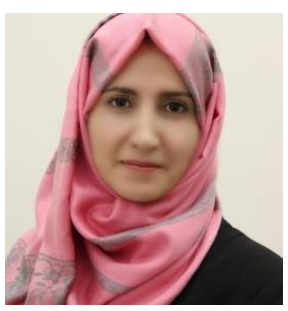

Barween Al Kurdi is an assistant Professor in Marketing and she is working for Amman Arab University - Faculty of Business - Marketing Department. She is a member of large number of committees and mainly the social committee. She used to publish in good ranked journals such as Journal of Marketing Communications and International Journal of Marketing Studies. You can contact D. Al Kurdi at balkurdi@ aau.edu.jo.

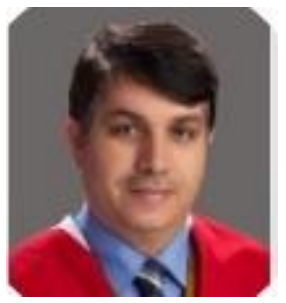

Muhammad Alshurideh is working for Fujairah University in UAE as Dean of Faculty of Business and as fulltime lecturer for the University of Jordan. Regarding the teaching, he has the responsibilities to teach a wide range of marketing and business topics for both undergraduate and postgraduate students. The D. has more than 33 published papers in different marketing and business topics mainly CRM and Customer Retention areas. D. Alshurideh is used to publish in good ranked journals such as Journal of Marketing Communications and International Journal of Electronic Customer Relationship Management. You can contact D. Alshurideh via emails at: m.alshurideh@ju.edu.jo or m.shurideh@uof.ac.ae.

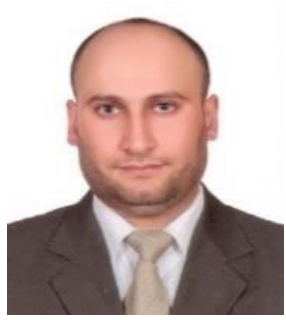

Said A. Salloum had graduated from The British University in Dubai with a distinction with MSc in Informatics (Knowledge and Data Management). He got his Bachelor's degree in Computer Science from Yarmouk University. Currently, He is working at the University of Sharjah "Research Institute of Sciences and Engineering (RISE)" as a researcher on different research areas in Computer Science such as data analysis, machine learning, knowledge management, and Arabic Language Processing. Salloum is an Oracle expert since 2013, along with various recognized international certificates that are issued by Oracle. You can contact. Said Salloum via emails at: ssalloum@sharjah.ac.ae or salloum78@live.com. 